\title{
Pociones sexuales. Relación entre alcohol, drogas y sexo.
}

\section{Sex potions. Relationships between alcohol, drugs and sex.}

\author{
Mark A. Bellis*, Karen Hughes** \\ * Director, Centre for Public Health. Liverpool John Moores University. \\ ** Investigador principal (Principal Researcher), Club Health.
}

Enviar correspondencia a:

Mark A Bellis. Centre for Public Health. Faculty of Health and Applied Social Sciences. Liverpool John Moores University. 8 Marybone.Liverpool, L3 2AP. UK. Tel: +44 (0)151231 5872. Fax: +44 (0)151231 5873. Email: m.a.bellis@livjm.ac.uk

\section{RESUMEN}

A lo largo de la historia, el consumo de drogas y de alcohol ha estado íntimamente ligado a la conducta sexual. A pesar de ello, sin embargo, casi todos los esfuerzos por mejorar la salud sexual y reducir los niveles de consumo de drogas y alcohol se ocupan de ambos problemas como si fueran independientes. Con una disponibilidad potencialmente mayor que nunca de sustancias que tienen efectos relacionados con el sexo, analizar los vínculos entre sexo y consumo de drogas se ha convertido en un factor crítico para tratar ambos problemas. En el presente estudio nos ocupamos de las relaciones entre alcohol, drogas y conducta sexual, incluyendo el consumo de afrodisíacos y facilitadores sexuales, de cómo las sustancias están cada vez más vinculadas a la violencia sexual, y de cómo el propio sexo puede ser un medio para obtener drogas. Analizamos cómo aquellos que consumen drogas y alcohol son sexualmente más activos, tienen más posibilidades de practicar un sexo poco seguro $y$, por ese motivo, mayor riesgo de enfermedades de transmisión sexual o de embarazos no deseados. Vemos cómo los servicios de asistencia para el consumo de drogas y la salud sexual pueden beneficiarse de un acercamiento entre ambos problemas. Finalmente, en el área de la prevención, estudiamos cómo los servicios de salud sexual pueden utilizar las imágenes relacionadas con la droga para dirigirse a quienes corren el riesgo de contraer enfermedades de transmisión sexual, y cómo esas iniciativas cada vez mayores en la prevención de drogas deben desafiar la imagen sexual de muchas substancias a fin de reducir su atractivo.

Palabras clave: uso recreativo de drogas, conductas de riesgo, practicas sexuales, enfermedades de transmisión sexual, prevención.

\section{ABSTRACT}

Throughout history drug and alcohol use has been intimately linked with sexual behaviour. Despite this however most attempts to improve sexual health and reduce levels of drug and alcohol use treat them as separate issues. With the availability of substances that have sex related effects potentially greater than ever, examining the links between sex and substance use has become a critical factor in addressing both issues. Here we discuss the relationships between alcohol, drugs and sexual behaviour, including the use of drugs as aphrodisiacs and sexual facilitators, how substances are increasingly being implicated in sexual assault, and how sex itself can be a means of obtaining drugs. We examine how those who use alcohol and drugs are more sexually active, more likely to practise unsafe sex, and hence at greater risk of sexually transmitted infections and unwanted pregnancy. We consider how treatment services for substance use and sexual health may benefit from an understanding of each other issues. Finally in the area of prevention, we discuss how sexual health services might utilise drug related imagery to target those at risk of sexual transmitted infections and how those developing drug prevention initiatives must challenge the sexual image of many substances in order to reduce their appeal.

Key words: recreational use of drugs, risk behaviour, sexual behaviour, sexual transmitted illness, prevention. 
as relaciones entre sexo, drogas y alcohol han sido claras y han estado muy bien documentadas durante cientos de años. Las llamadas pócimas amorosas han servido de ayuda sexual (normalmente cuando los hombres perseguían a una mujer) en textos antiguos, clásicos y contemporáneos (por ejemplo, Faraone, 2001; Shakespeare, 1996). En realidad, dichas pócimas eran a menudo plantas u otras substancias con propiedades psicoactivas destinadas a excitar o a desorientar un individuo, y con frecuencia eran administradas sin su conocimiento. Menos oscura pero también muy conocida es la relación histórica, en los dos sexos, entre el consumo de alcohol y la desinhibición sexual (por ejemplo, Martín, 2001) y la costumbre de animar a beber alcohol a otra persona para aumentar las probabilidades de actividad sexual. En la actualidad, existen potencialmente muchas más substancias disponibles que tengan efectos sobre el sexo que en cualquier otra época. Además, acceder a ellas es relativamente fácil y el conocimiento de sus efectos está muy extendido. Sin embargo, a pesar de esto y de los cientos de años que llevan conociéndose los vínculos entre sexo y consumo de drogas, la mayoría de los enfoques que tratan de resolver el deterioro de la salud sexual (por ejemplo, las enfermedades de transmisión sexual y los embarazos no deseados) o el aumento en los niveles de consumo de droga y alcohol siguen tratando ambos problemas como si fueran independientes.

En nuestros días, las pociones sexuales incluyen tanto aquellas sustancias con cientos de años de antigüedad como esas otras drogas de diseño a menudo desarrolladas específicamente por sus efectos psicoactivos y rápidamente incorporadas a la actividad sexual. Así, el cannabis lleva un largo tiempo vinculado a la conducta sexual y, al tratarse de la droga recreativo más empleada, se consume con frecuencia antes y después de practicar el sexo. Se considera que aumenta el placer sexual al estimular la relajación y aumentar el sentido del tacto (Buffum, Moser y Smith, 1988). No obstante, las mismas propiedades relajantes pueden ir ligadas a niveles más bajos en la práctica de un sexo seguro vinculado al consumo de cannabis (Poulin y Graham, 2001). La cocaína tiene también una larga historia sexual y entre los consumidores de drogas recreativas tiene mucha fama de ser un afrodisíaco (Gay, Newmeyer, Perry et al., 1982)) con propiedades que ayudan a retrasar el orgasmo y, por consiguiente, a prolongar el sexo (Buffum et al., 1988). Además, sus efectos y los de otras drogas pueden llevar a continuar practicando el sexo a pesar de las abrasiones genitales y, por ese motivo, aumentar el riesgo de transmisión de infecciones. Los consumidores de drogas valoran, asimismo, las anfetaminas por su capacidad de incrementar el deseo sexual e intensificar y prolongar el orgasmo (Buffum et al., 1988); y más recientemente encontramos el GBH (gammahidroxibutirato), al que se atribuyen fuertes propiedades afrodisíacas, en numerosos escenarios de vida nocturna. Así, por ejemplo, en una encuesta reciente (Calafat, Fernán-
$\mathbf{T}$ he relationships between sex, drugs and alcohol have been well established and well documented for thousands of years. Classically, so called love potions have featured as sexual aides (usually in men's pursuit of women), in ancient, classical as well as contemporary texts (e.g. Faraone, C., 2001; Shakespeare, W., 1996). In reality, such potions were often plants and other substances with psychoactive properties aimed at either exciting or disorientating an individual and were often administered without their knowledge. Less covert but also well recognised is the historical relationship, in both sexes, between alcohol consumption and sexual disinhibition (e.g. Martin, L., 2001) and the routine behaviour of one person plying another with alcohol in order to improve the likelihood of sexual activity. Today there are potentially more substances available with sex related effects than at any other time. Furthermore, accessing them is relatively easy and knowledge of their effects is widespread. However, despite this and thousands of years of knowledge intimately linking sex and substance use, most approaches to tackling either declining sexual health (i.e. sexually transmitted infections and unplanned pregnancy) or increasing levels of drug and alcohol use treat them as separate issues.

Today's sex potions include both those dating back hundreds of years and other designer drugs often developed specifically for their psychoactive effects but then rapidly incorporated into sexual activity. Thus, cannabis has been linked with sexual behaviour for centuries and as the most commonly used recreational drug is frequently consumed before and after sex. It is considered to increase sexual enjoyment by promoting relaxation and increasing sense of touch (Buffum, J., Moser, C. and Smith, D., 1988). However, the same relaxing properties may also be linked to reduced levels of safe sex practise associated with cannabis use (Poulin, C. and Graham, L. 2001). Cocaine also has a long sexual history and amongst recreational drug users has a strong reputation as an aphrodisiac (Gay, G.R., Newmeyer, J.A., Perry, M. et al., 1982). with properties that help delay orgasm and hence prolong sex (Buffum, J. et al., 1988). Further, its effects and those of other drugs may also lead to sex continuing despite genital abrasions and consequently increase the risk of infections being transmitted. Drug users also value amphetamine for its ability to increase sexual desire and enhance and prolong orgasm (Buffum, J. et al., 1988), and more recently GHB (Gammahydroxybutyrate) has been reported in many nightlife settings and accredited with strong aphrodisiac properties. For instance, in a recent survey (Calafat, A., Fernandez, C., Juan, M., Anttila, A. H., Arias, R., Bellis, M. A. et al. 2003) one female clubber from Holland stated: 
dez, Juan, Anttila, Arias, Bellis, et al. 2003) una clubber holandesa afirmaba:

"Me siento tan excitada y caliente después de tomar GHB que mi desinhibición es total. Me subo literalmente en cualquier cosa que parezca un hombre"

De hecho, el GHB ha estado presente en el ambiente social gay durante más de una década. Y, sin embargo, además de sus evidentes propiedades afrodisíacas, recientes investigaciones han mostrado que sus efectos de desinhibición afectan negativamente a la salud sexual (Bellis, Cook, Clark, et al., 2002). Durante un brote de sífilis, el $61 \%$ de los hombres gays infectados reconoció haber consumido GHB como potenciador sexual, alegando que tenía efectos afrodisíacos y les permitía olvidar sus inhibiciones cuando practicaban el sexo con extraños (Cook, Clark, Bellis, et al., 2001) Por otra parte, los individuos reconocieron haber consumido GHB concretamente para olvidar los mensajes de sexo seguro, a fin de poder disfrutar con tranquilidad de un gran número de parejas sexuales diferentes. Así, 23 individuos infectados de sífilis habían tenido casi 1500 parejas sexuales nuevas y casi siempre anónimas en los últimos doce meses. Más de la cuarta parte de los individuos que habían contraído sífilis eran seropositivos.

El éxtasis, arquetípica droga de club, se asoció antes a las propiedades sensuales que a las sexuales y adquirió fama de estimular los sentimientos táctiles y de empatía de los consumidores, pero no forzosamente su sexualidad (Measham, Aldridge, y Parker, 2001). Sin embargo, esa imagen del éxtasis puede estar relacionada con la aparición del HIV al mismo tiempo y, consecuentemente, con el temor a una práctica despreocupada del sexo. Una imagen de droga sensual pero no sexual podría haber ayudado a extender el éxtasis entre una juventud preocupada por el SIDA. El miedo al HIV y al SIDA parece haber disminuido en las psiques de los jóvenes y el éxtasis lleva algún tiempo presentándose, al igual que otras drogas, como una sustancia potenciadora del deseo sexual (Zemishlany, Aizenberg y Weizman, 2001). Con todo, a pesar del consumo cada vez mayor de éxtasis y otras drogas recreativas, el alcohol es la sustancia más empleada para alterar el comportamiento sexual.

Los dos sexos consumen alcohol para adquirir confianza en el momento de acercarse e interactuar con potenciales parejas sexuales (Abrahamson, 2004). El alcohol puede emplearse como un desinhibidor temporal que despierte el deseo sexual en los individuos que de otro modo serían más cautos. Al igual que otras drogas, el alcohol tiene propiedades amnésicas que permiten a los individuos olvidar sus acciones o las consecuencias de éstas antes, durante y después de la actividad sexual. Cuando los jóvenes se emborrachan, se duplican sus probabilidades de practicar sexo desprotegido (Traeen y Kvalem, 1996). A pesar de ello, la naturaleza legal del alcohol implica que las compañías de bebidas pueden exagerar y adornar las relaciones
"I get so excited and horny after taking GHB that I'm totally disinhibited. I literally climb onto everything that looks male"

In fact, GHB has featured as part of gay social scenes for over a decade. However, along with apparent aphrodisiac properties, recent research suggests its disinhibiting effects are also adversely affecting sexual health (Bellis, M. A., Cook, P., Clark, P. et al., 2002). During a syphilis outbreak, $61 \%$ of infected gay men reported use of GHB as a sex aid, claiming it had aphrodisiac effects and enabled them to lose their inhibitions when having sex with strangers (Cook, P. A., Clark, P., Bellis, M. A. et al., 2001). In addition however, individuals reported using GHB specifically to forget safe sex messages so that they could enjoy large numbers of sexual partners without concern. Thus, just 23 individuals diagnosed with syphilis had managed to accrue almost 1500 new, mostly anonymous, sexual partners in the past 12 months. Furthermore, over a quarter of those infected with syphilis were also HIV positive.

The archetypal club drug ecstasy was first associated with sensual rather than sexual properties and much was made of users feeling empathic and tactile but not necessarily sexually aroused (Measham, Aldridge, and Parker, 2001). However, this image of ecstasy may have been related to the emergence of HIV at the same time and the consequent fear of carefree sex. An image as a sensual but not sexual drug could have helped spread ecstasy throughout a youth concerned about AIDS. HIV and AIDS appear to have receded from youth psyche and for some time ecstasy has been reported, like other drugs, to increase sexual desire (Zemishlany, Aizenberg and Weizman, 2001). However, despite rapidly increasing levels of ecstasy and other recreational drug use, the substance used most commonly to alter sexual behaviour is alcohol.

Both sexes use alcohol to increase confidence when approaching and interacting with potential sexual partners (Abrahamson, 2004). Alcohol can be used as a temporary dissinhibitor making individuals agreeable to sex when they would otherwise be more cautious. Equally, like other drugs alcohol has amnesic properties that allow individuals to forget their actions or the consequences of their actions before, during and after sexual activity. Young people are more than twice as likely to have unprotected sex when they are drunk (Traeen y Kvalem, 1996). Despite this, the legal nature of alcohol means that drink companies can further embellish the relationship between alcohol and sex suggesting through advertisements that consuming alcohol increases the user's sex appeal and social prowess (Eurocare, 2001). However, while consuming modest amounts of alcohol may increase users' confidence large amounts frequently leave individuals vulnerable 
entre el alcohol y el sexo sugiriendo a través de la publicidad que el consumo de alcohol aumenta el atractivo sexual del consumidor y su habilidad social (Eurocare, 2001). No obstante, mientras consumir pequeñas cantidades de alcohol puede aumentar la confianza del individuo, consumir grandes cantidades suele hacerlo vulnerable a avances sexuales no deseados y volverlo incapaz de gestionar un sexo seguro (Johnson y Stahl, 2004).

Por lo general, los individuos pueden no llegar a entender los efectos que el alcohol o las drogas tienen en su comportamiento sexual y, sin embargo, elegir consumirlos. Aunque para una minoría cada vez más numerosa el hecho de exponerse a unas sustancias que alteran su comportamiento sexual no es una elección. Sabemos que las drogas se están empleando, subrepticiamente y de modo creciente, para dejar a unas víctimas semiinconscientes $y$, por ese motivo, incapaces de oponerse a un ataque sexual. Muchos de estos delitos quedan sin denuncia, ya que la amnesia es frecuentemente un efecto secundario de varias drogas para la violación en citas (EMCDDA, 2002; Schwartz, Milteer y LeBeau, 2000). Los casos denunciados, sin embargo, suelen implicar la administración clandestina de sustancias como Rohipnol (y otras benzodiacepinas), GHB y ketamina mezcladas con las bebidas en los lugares de reunión (Schwartz et al., 2000). Sólo en Gran Bretaña, el número de incidentes de violación en citas denunciadas en una asociación nacional de carácter benéfico pasó de 39 en 1990 a 935 en 2002; sólo uno de cada ocho casos fue denunciado a la policía (The Roofie Foundation, 2003). En algunos países, por ejemplo Nueva Zelanda, también se considera violación con drogas cuando alguien las consume a sabiendas, pero quien se las suministra se aprovecha de su estado de semiinconsciencia para cometer actos sexuales (Jansen, 2004; New Zealand Herald, 2003). Sin embargo, a pesar de que casi toda la atención se ha centrado en el consumo de drogas ilegales, lo cierto es que la sustancia más detectada, con diferencia, en esos casos de violación con drogas es el alcohol (por ejemplo, EISohly y Salamone, 1999). Utilizar el alcohol como una droga para la violación en citas implica que unos individuos empujen a otros a beber mucho más de lo que desean, pidiendo subrepticiamente para ellos mayores cantidades de alcohol o añadiendo licores adicionales a las bebidas existentes. A pesar de todo, sólo el alcohol puede producir desinhibición, episodios amnésicos y pérdida de conciencia, y, como la mayoría de los individuos beben alcohol cuando se relacionan entre sí, es difícil distinguir lo que se ha administrado de forma encubierta y lo que se ha consumido voluntariamente.

En algunas circunstancias, no es que las drogas sean un medio para practicar el sexo, sino que el sexo se convierte en un medio para conseguir las drogas. Por ejemplo, el consumo abusivo de drogas suele ser una característica de la prostitución callejera, en el caso de esas mujeres que sólo trabajan para obtener la droga que necesitan habitualmente (un $80 \%$ de las mujeres to unwanted sexual advances and incapable of negotiating safe sex (Johnson and Stahl, 2004).

In general, individuals may not fully understand the effects that alcohol or drugs have on their sexual behaviour but nevertheless choose to consume them. However, for a growing minority exposure to substances that alter sexual behaviour is not by choice. Increasingly, drugs are reported as being covertly used to render victims semi-conscious and hence incapable of preventing a sexual assault. Many such offences go unreported as amnesia is a common side effect of several date rape drugs (EMCDDA, 2002; Schwartz, Milteer and LeBeau, 2000). However reported cases often involve the surreptitious administration of substances like Rohypnol (and other benzodiazepines), GHB and ketamine via drinks in social settings (Schwartz, R. H. et al., 2000). In Britain alone alleged incidents of drug rape reported to a national charity increased from 39 in 1990 to 935 in 2002, with less than one in eight being reported to police (The Roofie Foundation, 2003). In some countries (e.g. New Zealand) drug rape is now also considered to have occurred when someone is knowingly provided with drugs but the supplier then takes advantage of their stupefied condition to commit sex acts (Jansen, 2004; New Zealand Herald, 2003). However, while much attention has focused on the use of illegal drugs, by far the most common substance detected in those reporting drug rape is alcohol (e.g. ElSohly and Salamone, 1999). Using alcohol as a date rape substance may involve individuals pressurising others to drink greater quantities than they wish, covertly ordering them larger drinks or adding additional spirits to existing drinks. Regardless, alcohol alone can result in dissinhibition, amnesic episodes and loss of consciousness, and as most individuals drink alcohol when socialising it is difficult to distinguish what has been covertly administered from what has been voluntarily consumed.

Rather than drugs being a means to have sex, in some circumstances sex becomes the means to have drugs. For instance, problematic drug use is often a feature of street prostitution with women working specifically to feed their drug habit (e.g. $80 \%$ working on the streets of Liverpool, UK, are addicted to heroin and three quarters to crack cocaine; Clark, Bellis, Cook et al., 2004). Frequently, such prostitutes are trapped in a worsening cycle of sex work and drug use. Here, they can only fund their drug use through selling sex but the indignity they feel and maltreatment they receive while working leads to a worsening drug habit (Plant, Plant, Peck et al., 1989). and therefore the need to work more. Throughout this cycle the sexual health of prostitutes and their clients is threatened as unprotected sex usually commands a higher price from clients (Morgan Thomas, Plant, 
que trabajan en las calles de Liverpool, en el Reino Unido, son adictas a la heroína y tres cuartas partes a la cocaína crack; Clark, Bellis, Cook et al., 2004). Con frecuencia esas prostitutas se ven atrapadas en una espiral de trabajo sexual y consumo de drogas. El único modo de conseguir dinero para la droga que necesitan es vender sexo, pero el sentimiento de indignidad y los malos tratos que reciben las empujan a aumentar el consumo de drogas (Plant, Plant, Peck et al., 1989) y, por ese motivo, a trabajar más. Durante todo ese ciclo, la salud sexual de las prostitutas y de sus clientes se ve amenazada, ya que el sexo desprotegido suele ser más caro para los clientes (Morgan Thomas, Plant, Plant et al., 1990). y las prostitutas que necesitan droga están dispuestas a vender sexo anal y vaginal sin preservativos a cambio de un precio más elevado. Semejante proceder puede parecer muy alejado del consumo de drogas recreativas. De forma anecdótica, sin embargo, debido al aumento de la popularidad de algunas drogas como la cocaína en el ámbito de la vida nocturna, algunas clubbers ofrecen sexo a cambio de drogas especialmente al final de la noche cuando el dinero escasea. Una vez más, el sexo sin preservativo parece estar mejor pagado.

En el caso de los hombres, existe al menos un factor adicional que puede vincular el consumo problemático de drogas con el sexo. Algunos datos de drogodependientes italianos muestran como tienen diez veces más probabilidades de tener una historia de disfunción eréctil que otros varones de la población general (La Pera, Giannotti, Taggi et al., 2003). Los individuos declararon haber empezado a consumir drogas específicamente para mejorar su actividad sexual o superar sentimientos de insuficiencia sexual. La hipótesis de que un elevado consumo de drogas, problemático o no, es el resultado de unos individuos haciendo frente a sus problemas sexuales necesita ser más investigada. No obstante, el consumo recreativo de drogas de prescripción para atajar al menos la impotencia inducida por alguna sustancia está ya muy extendido.

El consumo de alcohol, anfetaminas y éxtasis, especialmente abusivo, ha sido asociado con la impotencia masculina temporalmente inducida (Money, Leal y Gonzalez-Heydrich, 1988; Buffum, J. et al., 1988). Hasta cierto punto, esta respuesta fisiológica habría impedido el sexo desprotegido en aquellos varones incapaces de pensar en las consecuencias, habría reducido los niveles de sexo en las fiestas a altas horas de la madrugada, donde el éxtasis y otros estimulantes gozan de enorme popularidad, e incluso habría disminuido el número de violaciones por parte de quienes han bebido en exceso o han consumido demasiada droga. Sin embargo, las drogas para la disfunción eréctil (por ejemplo, Sildenafil, es decir, Viagra) se han incorporado también rápidamente a la cultura de la vida nocturna, y los hombres las consumen para contrarrestar la impotencia inducida por alguna sustancia y las mujeres para intensificar el orgasmo (Romanelli, y Smith, 2004; Caruso, Intelisano, Farina et al., 2003). De hecho, el Sextasy, un comprimi-
Plant et al., 1990). and prostitutes most in need of drugs are prepared to sell anal and vaginal sex without condoms in exchange for higher payments. Such behaviour may seem distant from recreational drug use. Anecdotally however, as drugs like cocaine increase in popularity across nightlife settings, some female clubbers are reported to offer sex for drugs especially at the end of the evening when money may be short. Again, sex without condoms is likely to attract a higher premium.

For men at least an additional factor may link problematic drug use and sex. Data from Italian drug addicts identified them as being ten times more likely to have a history of erectile dysfunction than males in the general population (La Pera, Giannotti, Taggi et al., 2003). reported that drug use was initiated specifically to improve sexual activity or overcome feelings of sexual inadequacy. The hypothesis that much drug use, problematic or otherwise, results from individuals coping with sexual problems requires further investigation. However, the recreational use of prescription drugs to tackle at least substanceinduced impotency is already widespread.

Consumption of alcohol, amphetamine and ecstasy, especially in excess, have all been associated with temporarily inducing male impotence (Money, Leal and Gonzalez-Heydrich, 1988; Buffum, J. et al., 1988). To some extent this physiological response will have prevented unprotected sex by males who are incapable of considering the consequences, restricted levels of sex at late night parties where ecstasy and other stimulants are popular and may even have reduced rape by those drunk or high on drugs. However, drugs for erectile dysfunction (e.g. Sildenafil i.e. Viagra) have also been rapidly incorporated in nightlife culture and are consumed to counteract substance-induced impotence in men as well improve orgasm in women (Romanelli, and Smith, 2004; Caruso, Intelisano, Farina et al., 2003). In fact, Sextasy, a combined tablet of ecstasy and Viagra, is now being reported on club scenes (Breslau, 2002). and in the UK, up to $8 \%$ of those attending some dance events have used Viagra (Deehan and Saville, 2003). Furthermore, research among gay and bisexual men found that Viagra users had greater numbers of recent sexual partners, higher levels of unprotected anal sex (among HIVnegative participants) and higher rates of STIs (Kim, Kent and Klausner, 2002).

On an international basis an estimated 32,000 tons of cannabis, 655 tons of cocaine, and 1.4 billion ecstasy tablets are produced annually, with consumption of all substances increasing at a global level (UNODC, 2004). Across Europe, use of stimulant drugs such as ecstasy, amphetamine and cocaine are highest among young people (EMCDDA, 2003), and are particularly high among 
do que combina éxtasis y Viagra, está ya presente en los clubs nocturnos (Breslau, 2002) y en el Reino Unido, más del $8 \%$ de quienes acuden a bailar han empleado Viagra (Deehan y Saville, 2003). Además, algunos estudios realizados entre hombres gays y bisexuales descubrieron que los consumidores de Viagra tenían mayor número de parejas sexuales nuevas, niveles más elevados de sexo anal desprotegido (entre participantes de HIV negativo) y un porcentaje más alto de enfermedades de transmisión sexual -ETS- (Kim, Kent y Klausner, 2002).

Partimos de la base de que en el mundo se producen anualmente alrededor de 32.000 toneladas de cannabis, 655 toneladas de cocaína y 1.4 billones de pastillas de éxtasis, y de que el consumo de todas estas sustancias aumenta a nivel global (UNODC, 2004). En Europa, el consumo de drogas estimulantes como el éxtasis, la anfetamina y la cocaína está muy extendido entre la juventud (EMCDDA, 2003), y es especialmente elevado entre determinados subgrupos de población, como el de quienes acuden a los clubes nocturnos (por ejemplo, Deehan y Saville, 2003). Por otra parte, en muchos países también continúa aumentando el consumo de alcohol entre los jóvenes, y la costumbre de beber hasta intoxicarse, emborracharse y consumir drogas ilegales entre estudiantes de 15 o 16 años se ha incrementado en casi todos los países europeos entre 1995 y 1999 (Hibell y col., 2001). Ese aumento en el consumo de sustancias ha venido acompañado de niveles cada vez más altos de enfermedades de transmisión sexual. Entre 1995 y 2000, se han diagnosticado un $20 \%$ más de nuevos casos de HIV por contagio sexual en Europa occidental, con prevalencia de otras ETS, incluyendo la incidencia cada vez mayor de gonorrea y sífilis en muchos países (Nicoll y Hamers, 2002). A menudo este incremento afecta de forma desproporcionada a los jóvenes (por ejemplo, la clamidia llegó casi a triplicarse entre los jóvenes del Reino Unido entre 1995 y 2003; Departamento de Protección de la Salud, 2004) y no se limita al ETS, pues en algunos países incluye embarazos no deseados y abortos (Servicio Estadístico Gubernamental del Reino Unido, 2004).

Esas tendencias no son por sí solas una prueba evidente de la causa y del efecto y las propiedades sexuales atribuidas a las drogas pueden ser en parte un placebo (Critchlow Leigh, 1990). Desde luego, se necesitan nuevas investigaciones para determinar el papel que juegan exactamente las drogas y el alcohol en los problemas de salud sexual. Sin embargo, la introducción de mayor número de conductas que alteran las drogas e incrementan el consumo de alcohol en los ámbitos juveniles tiene que relajar inevitablemente las costumbres sexuales y, por consiguiente, aumentar el sexo libre y despreocupado. Así, el estudio indica que quienes consumen drogas y alcohol no sólo tienen más posibilidades de practicar el sexo que sus iguales no consumidores, sino también de tener más parejas sexuales y de practicar el sexo sin preservativos. De igual modo, aquellos que consumen drogas y alcohol a certain subgroups of the population such as those that visit nightclubs (e.g. Deehan and Saville, 2003). Furthermore, in many countries, alcohol consumption also continues to increase amongst young people and levels of binge drinking, drunkenness and illicit drug use among 15-16 year old schoolchildren increased in most European countries between 1995 and 1999 (Hibell, Andersson, Ahlstrom et al., 2001). Such increases in the consumption of substances have been accompanied by increasing levels of sexually transmitted infections. Between 1995 and 2000, new diagnoses of sexually acquired HIV increased by $20 \%$ in Western Europe, with prevalence of other STIs including gonorrhoea and syphilis also increasing in many countries (Nicoll and Hamers, 2002). Often these increases are disproportionately affecting the young (e.g. Chlamydia in young people almost tripled between 1995 and 2003 in the UK; Health Protection Agency, 2004) and are not limited to STIs but in some countries include unwanted pregnancies and terminations (UK Government Statistical Service, 2004).

Such corresponding trends alone are not evidence of cause and effect and the sexual properties attributed to drugs may in part be placebo (Critchlow Leigh, 1990). Clearly, more research is required to establish the exact role that drugs and alcohol play in sexual health issues. However, the introduction of greater quantities of behaviour altering drugs and increasing use of alcohol into young people's social settings must inevitably relax sexual mores and consequently increase carefree and careless sex. Thus, research already suggests that those who use alcohol and drugs are not only more likely to have had sex than their non-using peers, but also to have more sexual partners and to have sex without using a condom. Equally, those who use drugs and alcohol at an earlier age have sex earlier (Calafat et al., 2003) and studies within Europe suggest up to a third of young people are under the influence of alcohol or drugs when they first have sex (Michaud, P. A. and Narring, F., 1997). Such sex is often regretted in retrospect (Bonomo, Coffey, Wolfe et al. 2001; Wight, Henderson, Raab et al., 2000).

Rising to the challenges posed by increasing drug use and sexually transmitted infections requires tackling both issues in an integrated fashion. Thus, young people requiring support for drug problems will frequently benefit from safe sex advice and access to Genito-urinary screening and services. Equally, individuals diagnosed with infections or with unwanted pregnancies may turn to alcohol or drugs for immediate comfort and are, in any case, more likely to be users. Thus, sexual health services that understand substance use issues will be more effective both at identifying the underlying reasons for unprotected sex and at providing a more holistic 
una edad más temprana se inician antes en la práctica del sexo (Calafat et al., 2003) y algunos estudios europeos muestran que un tercio de los jóvenes se encuentra bajo la influencia del alcohol o de las drogas al tener su primera experiencia sexual (Michaud y Narring, 1997). Al recordarla con posterioridad, dicha experiencia se lamenta a menudo (Bonomo, Coffey, Wolfe et al. 2001; Wight, Henderson, Raab et al., 2000).

Para estar a la altura de los retos planteados por el aumento de consumo de drogas y de las enfermedades de transmisión sexual debemos enfrentarnos a ambos problemas de un modo integrado. De ese modo, los jóvenes que necesiten ayuda para superar sus problemas con la droga se beneficiarán a menudo de los consejos para un sexo seguro y del acceso a los servicios y a las pruebas genito urinarias. Del mismo modo, es posible que los individuos a los que se haya diagnosticado una infección o un embarazo no deseado busquen en el alcohol o en las drogas un alivio inmediato $y$, en cualquier caso, tienen más probabilidades de ser consumidores. Así, los servicios de salud sexual que comprendan los problemas derivados del consumo de drogas serán más eficaces tanto para identificar las razones que subyacen en la práctica de un sexo desprotegido como para proporcionar una respuesta más holística. En la prevención de drogas, es posible que los mensajes resulten beneficiados al desafiar la imagen sexual de muchas drogas y productos alcohólicos de un modo similar al adoptado por los materiales antitabaco (Byrne, 2002). Asimismo, las campañas de salud sexual pueden emplear todas las imágenes vinculadas a las drogas, con el fin de dirigir los mensajes hacia el punto clave en los grupos de riesgo. Además, los encargados de promover la salud sexual se beneficiarán al comprender tanto el potencial sexual como los efectos desorientadores de las sustancias. En realidad, las intervenciones destinadas a reducir el consumo de alcohol en las chicas jóvenes, por ejemplo, pueden tener un impacto mayor en la mejora de la salud sexual que muchos programas que se ocupen directamente de los problemas de salud sexual. Por consiguiente, la reducción de daños relacionados con el alcohol y las drogas debe contemplarse como un elemento clave a la hora de proteger la salud sexual.

Durante los últimos veinte años, el acceso de los jóvenes a las drogas recreativas se ha incrementado de forma espectacular, y los viejos boticarios y los modernos farmacéuticos han dejado de ser los únicos que conocen sus efectos. Es posible que las drogas y el sexo sean hoy en día dos de los retos más difíciles a los que deban enfrentarse los profesionales de la salud, dados los problemas legales de las drogas y el hecho de que el sexo sea una parte privada del comportamiento del individuo. Pero la tarea de mejorar la salud sexual y de reducir el consumo de drogas podría simplificarse si, al igual que los jóvenes, los profesionales de la salud enfocaran estos temas tan difíciles como dos partes ligadas de un fenómeno social más amplio. response. In drug prevention, messages may benefit from challenging the sexual image of many drugs and alcohol products in a similar fashion to that adopted by anti-smoking materials (Byrne, 2002). Equally, sexual health campaigns can use imagery linked to drugs in order to target messages towards key at risk groups. Furthermore, those providing sexual health outreach will benefit from understanding both the potential sexual and disorientating effects of substances. In reality, interventions aimed at reducing alcohol consumption in, for instance young girls, may have a greater impact on improving sexual health than many programmes dealing directly with sexual health issues. Consequently, alcohol and drug related harm minimisation must be seen as key elements in protecting sexual health.

Over the past 20 years young people's access to recreational drugs has increased dramatically and the knowledge of their effects is no longer limited to ancient apocatharies or modern chemists. Drugs and sex may be two of the most difficult challenges faced by health professionals today with the former crossing legal issues and the latter being a private part of individuals' behaviour. However, the tasks of improving sexual health and reducing drug use may be made easier if, like young people, health professionals approach these difficult subjects as two linked parts of a wider social phenomenon.

\section{REFERENCIAS (REFERENCES)}

Abrahamson, M. (2004). Alcohol in courtship contexts: Focus-group interviews with young Swedish women and men. Contemporary Drug Problems; 31: 3-29.

Bellis, M. A., Cook, P., Clark, P. et al. (2002). Reemerging syphilis in gay men: a case-control study of behavioural risk factors and HIV status. Journal of Epidemiology and Community Health; 56: 235-236.

Breslau, K. (2002). The 'Sextasy' craze. Newsweek, 139: 30.

Bonomo, Y., Coffey. C. and Wolfe. R. et al. (2001). Adverse outcomes of alcohol use in adolescents. Addiction, 96: 1485-1496.

Buffum, J., Moser, C. and Smith, D. (1988). Street drugs and sexual function. In Sitsen JMA. Handbook of Sexology. Volume VI. The pharmacology and endocrinology of sexual function. Amsterdam. Elsevier.

Byrne, D. (2002). Feel free to say no: Brochure 2002. Luxembourg: EC Health and Consumer Protection Directorate-General. 
Calafat, A., Fernandez, C., Juan, M., Anttila, A. H., Arias, R., Bellis, M. A. et al. (2003). Enjoying the nightlife in Europe: The role of moderation. Valencia. IREFREA.

Caruso, S., Intelisano, G., Farina, M., et al. (2003). The function of Sildenafil on female sexual pathways: a double-blind, cross-over, placebo-controlled study. European Journal of Obstetrics, Gynecology and Reproductive Biology, 110: 201-206.

Clark, P., Bellis, M. A., Cook, P. A. et al. (2004). Consultation on a managed zone for sex trade workers in Liverpool: Views from residents, businesses and sex trade workers in the City of Liverpool. Liverpool: Centre for Public Health, Liverpool John Moores University.

Cook, P. A., Clark, P., Bellis, M. A. et al. (2001). Reemerging syphilis in the UK: A behavioural analysis of infected individuals. Communicable Disease and Public Health, 4: 253-258.

Critchlow Leigh, B. (1990). The relationship of sex-related alcohol expectancies to alcohol consumption and sexual behaviour. British Journal of Addiction, 85: 919-928.

Deehan, A. and Saville, E. (2003). Calculating the risk: Recreational drug use among clubbers in the South East of England. London: Home Office.

EISohly, M. A. and Salamone, S. J. (1999). Prevalence of drugs used in cases of alleged sexual assault. Journal of Analytical Toxicology, 23: 141-146.

EMCDDA (2002). Report on the risk assessment of $\mathrm{GHB}$ in the framework of the joint action on new synthetic drugs. Luxembourg: Office for Official Publications of the European Union.

EMCDDA (2003). Annual Report 2003: The state of the drugs problem in the European Union and Norway. Lisbon: EMCDDA.

Eurocare (2001). Marketing alcohol to young people. St Ives: Eurocare.

Faraone, C. (2001). Ancient Greek love magic. Cambridge: Harvard University Press.

Gay, G.R., Newmeyer, J.A., Perry, M. et al. (1982). Love and haight: The sensuous hippy revisited. Drug/sex practices in San Fransisco, 1980-81. Journal of Psychoactive Drugs; 14: 111-123.

Health Protection Agency (2004). Focus on prevention. HIV and other sexually transmitted infections in the United Kingdom in 2003. London: Health Protection Agency.

Hibell, B., Andersson, B., Ahlstrom, S. et al. (2001). The 1999 Espad Report: Alcohol and other drug use among students in 30 European countries.
Stockholm: The Swedish Council for Information on Alcohol and Other Drugs (CAN).

Jansen, K. (2004). Ecstasy (MDMA), other club drugs and drug-facilitated sexual assault. Proceedings. Club Health 2004, April 18 ${ }^{\text {th }}-20^{\text {th }} 2004$, Melbourne, Australia.

Johnson, T. J. and Stahl, C. (2004). Sexual experiences associated with participation in drinking games. The Journal of General Psychology, 131: 304-320.

Kim, A. A., Kent, C. K. and Klausner, J. D. (2002). Increased risk of HIV and sexually transmitted disease transmission among gay or bisexual men who use Viagra, San Fransisco 2000-2001. AIDS, 16: 1425-1428.

La Pera, G., Giannotti, C. F., Taggi, F. et al. (2003). Prevalence of sexual disorders in those young males who later become drug abusers. Journal of Sex and Marital Therapy; 29: 149-156.

Martin, L. (2001). Alcohol, sex and gender in late medieval and early modern Europe. Palgrave: New York.

Measham, F., Aldridge, J. and Parker, H. (2001). Dancing on drugs: Risk, health and hedonism in the British club scene. London: Free Association Books.

Michaud, P. A. and Narring, F. (1997). Saturday night fever: circumstances of the first sexual intercourse among Swiss teenagers. Journal of Adolescent Health; 20: 167.

Money, J., Leal, J. and Gonzalez-Heydrich, J. (1988). Aphrodisiology: history, folklore, efficacy. In Sisten JMA. Handbook of Sexology. Volume VI: The pharmacology and endocrinology of sexual function. Amsterdam: Elsevier.

Morgan Thomas, R., Plant, M. A., Plant, M. L. et al. (1990). Risk of HIV infection among clients of the sex industry in Scotland. British Medical Journal, 301: 525 .

New Zealand Herald (2003). Restauranteur found to have sexually violated young men. $22^{\text {nd }}$ November 2003.

Nicoll, A. and Hamers, F. F. (2002). Are trends in HIV, gonorrhoea, and syphilis worsening in western Europe? BMJ, 324: 1324-1327.

Plant, M. L., Plant, M. A., Peck, D. F. et al. (1989). The sex industry, alcohol and illicit drugs: implications for the spread of HIV infection. British Journal of Addiction, 84: 53-9.

Poulin, C. and Graham, L. (2001). The association between substance use, unplanned sexual intercourse and other sexual behaviours among adolescent students. Addiction, 96: 607-621. 
Romanelli, F. and Smith, K. M. (2004). Recreational use of Sildenafil by HIV-positive and -negative homosexual/bisexual males. The Annals of Pharmacotherapy, 38: 1024-1030.

Ruetsch, Y. A., Boni, T., and Borgeat, A. (2001). From cocaine to ropivacaine: the history of local anesthetic drugs. Current Topics in Medicinal Chemistry; 1: 175-82.

Schwartz, R. H., Milteer, R. and LeBeau, M. A. (2000). Drug-facilitated sexual assault ('date rape'). Southern Medical Journal; 93: 558-61.

Shakespeare, W .(1996). A midsummer night's dream. In Staunton H (ed) (1996). The complete works of William Shakespeare. Hertfordshire: Wordsworth Editions Ltd.

The Roofie Foundation (2003). Statistical Update July 2003. Knaresborough: The Roofie Foundation.
Traeen, B. and Kvalem, I. L. (1996). Sex under the influence of alcohol among Norwegian adolescents. Addiction, 91: 995-1006.

UK Government Statistical Service (2004). Summary abortion statistics, England and Wales 2003. London: Department of Health.

United Nations Office on Drugs and Crime (UNODC) (2004). World Drug Report 2004. Geneva: United Nations Publications.

Wight, D., Henderson, M., Raab, G. et al. (2000). Extent of regretted sexual intercourse among young teenagers in Scotland. BMJ, 320: 12431244.

Zemishlany, Z., Aizenberg, D. and Weizman, A. (2001). Subjective effects of MDMA (,Ecstasy') on human sexual function. European Psychiatry, 16: 127130. 
